\title{
Developing Mobile Learning in the Early Childhood Education
}

\author{
Atin Fatimah ${ }^{1, *}$ Kristiana Maryani ${ }^{1}$ \\ ${ }^{1}$ Universitas Sultan Ageng Tirtayasa, Serang, Indonesia \\ *Corresponding author. Email: fatimah.79@untirta.ac.id
}

\begin{abstract}
The objectives of this research are (1) to develop mobile learning for early childhood, (2) to measure the effectiveness of mobile learning implementation for early childhood. Data analysis techniques using Milles and Hubberman and t-test to measure the effectiveness of "golden age" mobile learning. Based on the validation result, score of material test result is 3,00 and the result of media test is 3,31, while based on field trial it got a result score of 3,30. Scores of small group trial results on ten children obtained a score of Mean 65,5, Median 72 and Standard Deviation 16,9. Furthermore, based on the results of broader group trials as part of product improvements made to thirty children it achieved the scores of Mean 70.2, Median 72 and Standard deviation 0.33. In other words, the development of mobile learning for early childhood through media courses and learning resources at the Universitas Sultan Ageng Tirtayasa produces a fairly good product.
\end{abstract}

Keywords: Model development, mobile learning, children

\section{INTRODUCTION}

Education today lives in the world of media, where learning activities have moved towards increasing use of various forms and types of media. The role of learning media is very important in learning activities in early childhood. The current trend is the increasingly widespread use of communication facilities in the form of mobile learning based on the use of media that has penetrated into the world of children. Children are easy and quick to master the use of touch screens (Ibrahim, Borhan, \& Yatim, 2013, pp. 15). Computers and tablets, for example, can be used anywhere and anytime by children so that teachers prepare them at any time as needed to be used as learning devices (Melhuish \& Falloon, 2010).

The number of mobile users in Indonesia in 2012 is \pm 159 , 248.00, and mobile internet users in Indonesia that year has reached around 19 million users, an increase of 57 percent from the previous year of 16 million. The application of mobile learning will be a future innovation prospect that will further develop through mutually supportive learning applications in many brands of mobile phones.

Mobile learning technology is very motivating for children and far more interesting than presenting traditional tools in the classroom (Henderson \& Yeow, 2012, pp.78-87). On the other hand, the use of mobile learning for only learning is not optimal. From a number of mobile users in Indonesia, most of them are only intended for telephone, SMS and chat. The challenge is that there are not that many of mobile based learning content that is widely accessible. The majority of content circulating in the market is still dominated by entertainment content that has less educational aspects.
Based on the background of the problems described, the researcher needs to conduct research on the Development of Mobile Learning for Early Childhood in the Learning Resources and Learning Media Courses at the Sultan Ageng Tirtayasa University of Banten.

\section{RESEARCH METHOD}

This developmental research refers to the development model of Gall, Borg, and Gall (1989, p. 775), which is limited to just a few stages. These stages include: a) information collection stage, b) planning stage, c) product development stage, and d) validation and trial stages. Explanation of each stage carried out in this research and development is reviewed in the results of the research and discussion.

\section{RESULT AND DISCUSSION}

\subsection{Research Result}

\subsubsection{Phase of information gathering}

Begins with a syllabus or RPS review (semester learning plan). The RPS review is conducted by making a basic competency mapping (attached). Based on the RPS material obtained will be developed in the subject of learning resources and learning media, namely the making of media mobile learning for early childhood. The implementation of the learning outcomes of the course (CPMK) is able to make 
Android-Based Learning Media using Macromedia Flash which is designed and organized through practicum at 5 times ( $5 \times 3 \times 50$ Minutes) lecture meetings with a course weight of 3 credits.

In addition to reviewing the semester learning plan, preliminary research on information gathering was also conducted to recognize the initial behaviors relating to mastery and ability of the field of science in Learning Resources and Learning Media for early childhood students who already owned PG PAUD students and to recognize the initial characteristics of Kindergarten students. Especially at Kemala Bhayangkari Serang Kindergarten.

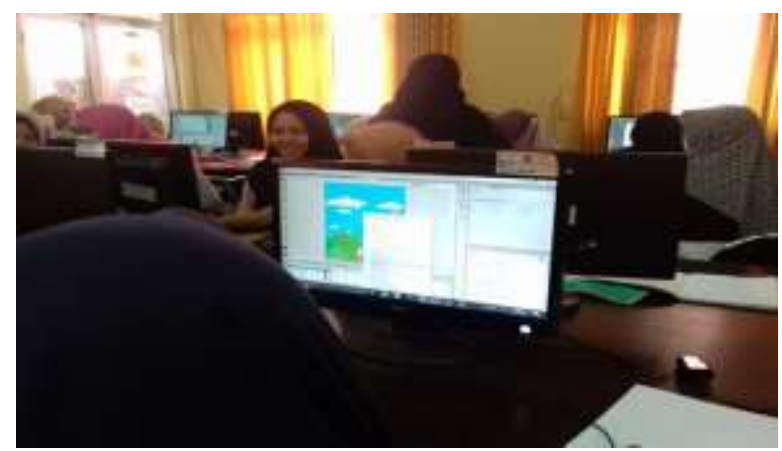

Figure 1 Mastery of competence in courses media and learning resources for early childhood

In addition to observations on Semester IV PG PAUD students who contracted the Course, preliminary research was also conducted with literature. Literature studies are carried out to obtain information from the results of research related to learning resource material that will be developed.

\subsubsection{Stage of planning}

The second phase consists of making a research instrument grid which becomes an assessment criterion for mobile learning early childhood. The instrument grid that has been compiled then developed into a research instrument. The research instruments that will be used are validation sheets, observation sheets and interview guidelines. Validation sheet is used to determine the feasibility of interactive learning media based on mobile learning based on the assessment of material experts and media experts. Material experts provide assessments based on material aspects, learning and language while media experts provide an assessment based on programming and display aspects. The observation sheet and interview guidelines are used to determine the responses and responses of teachers and students regarding the use of interactive learning media based on mobile learning.

The planning of this research was also realized in the form of design making carried out to make detailed specifications regarding material requirements for the concept of games which were subsequently developed by students according to the direction of the research team. Specifications are made in detail so that at the development stage no new decisions are needed.
Planning for the design of mobile based learning media is done through three stages as follows:

1) Determine the theme

Determine the theme of the game that is adapted to the theme of learning for early childhood.

2) Create a flowchart view

Flowchart view (display diagram) is a diagram that provides a flow picture from one scene to the next scene.

3) Storyboarding

Storyboards are guidelines for the flow of work that must be done.

In the storyboard there is a description of each scene that clearly describes the media object and its behavior. The storyboard of mobile learning development in this study is presented in the appendix

\subsubsection{Development phase}

At this stage the making of interactive learning media products is based on mobile learning. The steps taken are as follows; a) make a story board with the aim of facilitating the making of the media and to determine the next stage of development, so that the parts of the learning media can be arranged properly; b) make a layout. Layout is made by paying attention to aspects of color and composition; c) Layouts that have been completed are then filled with material relating to early childhood; d) After the material writing step, the media is then given animated videos and images that can support the material. In addition, it is also equipped with instructions for use that are made in the form of sound.

\subsubsection{The stage of validation and testing}

The media validation phase was carried out so that the interactive learning media that has been developed could be identified based on the assessment of material experts and media experts. Validation of interactive learning is done by: a) material experts who are competent in the PAUD field; and b) media experts who are competent in the field of interactive learning media based on mobile learning. The validated media products are then revised according to expert advice and input during the validation process.

After the interactive learning media was revised it was then carried out in the testing phase of the use of learning media in PAUD institutions, which aimed to find out the response of teachers and students based on the interactive mobile learning that has been developed. The trial phase was carried out at TK Kemala Bhayangkari I. This trial was conducted by using media in learning in a computer laboratory. During media use, observations are made on the use of the media. After using the media, the teacher and students were interviewed for their responses, suggestions, 
and comments about the interactive learning media developed.

The interactive learning media based on mobile learning has been revised and then revised again based on suggestions and input from teachers and students. Interactive learning media products based on mobile learning are packaged in the form of applications compiled using Adobe Flash.

\subsection{Results of Media Expert Validation and Material Experts}

Before conducting trials, mobile-based interactive learning media that was developed were validated in advance by media experts and material experts. Validation is carried out by experts who have backgrounds that relates with the media developed and have research experience in developing mobile learning, namely Dr. Aan Hendrayana, M.Pd., and Material experts who have a background in PAUD, Dr. Isti Rusdiyani, M.Pd. Validation by experts aims to obtain information, criticism, and suggestions so that interactive learning media based on mobile learning are developed into quality products in material aspects and language. The maximum score of each item statement in the validation sheet is 4 while the minimum score is 0 .

Tabel 1 Instrument material validation instrument

\begin{tabular}{|c|l|l|c|}
\hline No & Aspect & \multicolumn{1}{|c|}{ Indicator } & Value \\
\hline 1 & & Color quality & 4 \\
2 & & Sound quality & 3 \\
3 & \multirow{3}{*}{ Media } & Image display quality & 4 \\
4 & Display quality animation & 3 \\
5 & & Color composition & 4 \\
6 & & Ease of running the program & 2 \\
7 & & Clarity of instructions for using the media & 2 \\
\hline 8 & & Material provided according to the theme & 4 \\
9 & & Material provided according to age of development & 3 \\
10 & \multirow{2}{*}{ The Material } & Ease of understanding material & 3 \\
11 & & Material clarity in motivating children & 4 \\
12 & & Material presented sequentially and systematically & 3 \\
13 & & Clarity of language usage & 2 \\
\hline & Number & 39 \\
\hline & Percentage of & $75 \%$ \\
\hline
\end{tabular}

The results of expert validation show the results of a total score of 39 with a percentage of $75 \%$ and a mean score of 3 with categories sufficient.

Before conducting the trial, learning based on mobile learning media that has been developed was also validated in advance by media experts. Validation by media experts aims to get information, criticism, and suggestions thatbased learning media mobile learning developed into quality products in programming and appearance. The maximum score of each item statement in the validation sheet is 4 while the minimum score is 0 .

\subsection{Results of Product Revision}

Interactive learning media is based on mobile learning which was developed through the validation stage by material and media experts, before being tested. Based on the results of the validation by material experts and the media there are several parts to the learning media that must be corrected. In addition to improvements based on the assessment of material experts and media experts, learning media were also improved based on trials. The following is an explanation of the repair process:

\subsubsection{Revision of phase I}

Revision phase I was carried out by material experts and the media who gave suggestions, comments and input. The revisions made in this phase I revision are:

1) Expert Advice Material

a) The use of language is less operational and communicative. In the sentence, "let's select the fingers of the number XX!", we recommend using the sentence, "let's choose a finger image that shows XX numbers!"

b) In numeric games, 0 is not represented by a finger image $(0=$ no image $)$ 


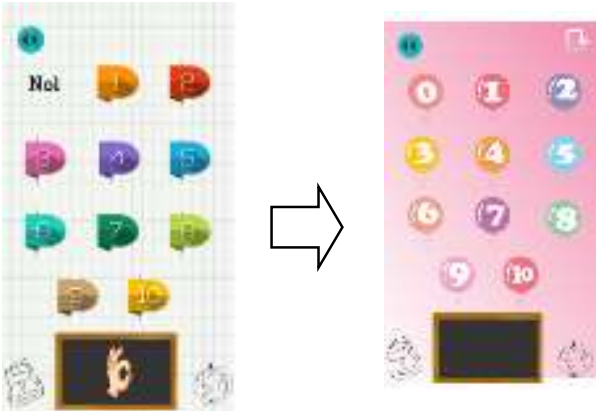

Figure 2 Changes in slide playing numbers with number representations that are not corresponding

c) The numbers on the "recognize me" menu on playing numbers should be thickened so that children's visual readability gets better

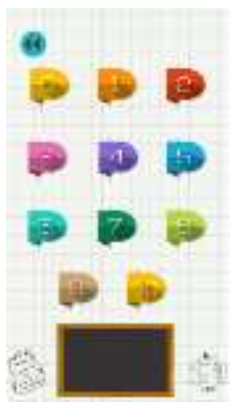

Figure 3 Thickening of numbers in slide playing numbers

2) Suggestion Media Experts

Media experts provide some input regarding things that need to be corrected in the application of learning media golden age. The following revisions are made according to expert media advice.

a) There is no clue. There should be a navigation button to exit each slide (escape).

b) Navigation keys help (help).

There are three navigation buttons provided for users of the game golden age, the start button for start the game, exit button to exit the game, and back button, which is presented only on a few game slides (note the circled 5.5). The following are the navigation buttons available on the "game application golden age" which is developed by the research team:

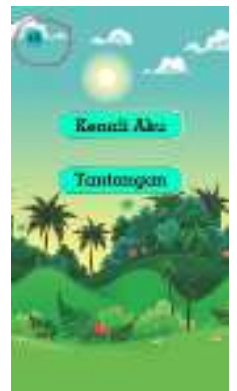

Figure 4 Navigation buttons at the golden age games

\subsubsection{Revision of phase II}

Revision phase II was carried out referring to suggestions, comments and observations during product trials and during interviews with users. The revisions made in this phase II revision are:

1) Sound used is less energetic, should be replaced with music that has a cheerful beat so that children are more interested in using the application.

2) The picture of a duck animal is like a bird so it confuses the child (note the circled picture)
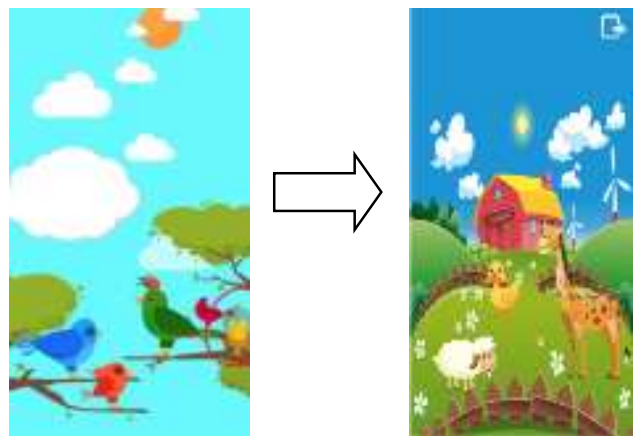

Figure 5 Changes in visualization of birds that resemble birds

3) The structure of the game should be sequential or continued so that children who have succeeded or finished in stage 1 of the game can proceed directly to the next game. (do not have to go back to the beginning to choose the next game)
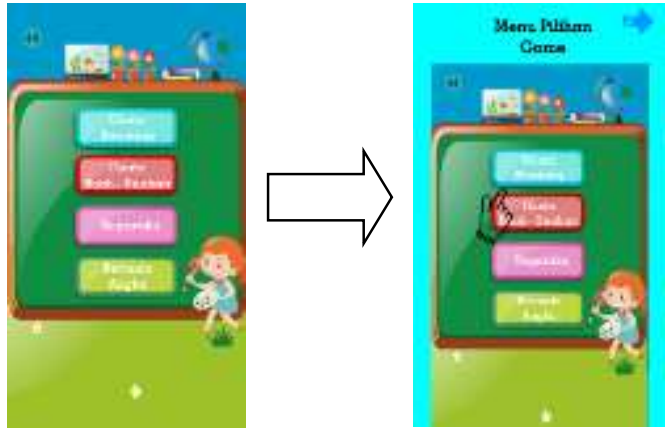

Figure 6 Changes in the menu selection for the game

\section{DISCUSSION}

\subsection{Development of Mobile Learning for Early Childhood}

This research has produced learning applications that can be used in group B children when using mobile learning. This application contains:

1) Interactive learning application that presents activities to recognize animal characteristics, fruit names, recognize the symbol of Pancasila as a representation of the theme of my country, and play numbers named "golden age". 
2) Interactive learning applications on the play numbers menu presents the ability of children to be able to say 1-10, recognize the concept of numbers with finger drawings and can designate symbols of numbers.

3) The interactive learning application invites children to actively participate and provide stimuli to solve their problems. Stimulation given to children is a simple question that stimulates the child to find the answer.

4) The mobile learning application provides a pleasant atmosphere. The pleasant atmosphere in the mobile learning application is stimulated through the existence of simple images, sounds, animations and games.

5) The mobile learning application uses simple language that is easily understood by children in group B (ages 5-6 years).

6) The mobile learning application has a layout that is made simple by only delivering one question on each slide and not using a lot of writing.

7) The mobile learning application presents interrelated relationships between visual and audio elements.

8) This mobile learning application is based on Android OS which has undergone a material testing process, media testing, limited field trials, wider field trials and refinement of final products.

\subsection{Effectiveness of Applications Mobile Learning for Early Childhood}

To find out the effectiveness of the application of mobile learning in PAUD institutions, the research team conducted a small group trial at TK Kemala Bhayangkari 1 Serang. Prelimitary field testing shows the results that are quite effective for the continuity of learning media mobile learning. The following observations obtained are presented in the following diagram:

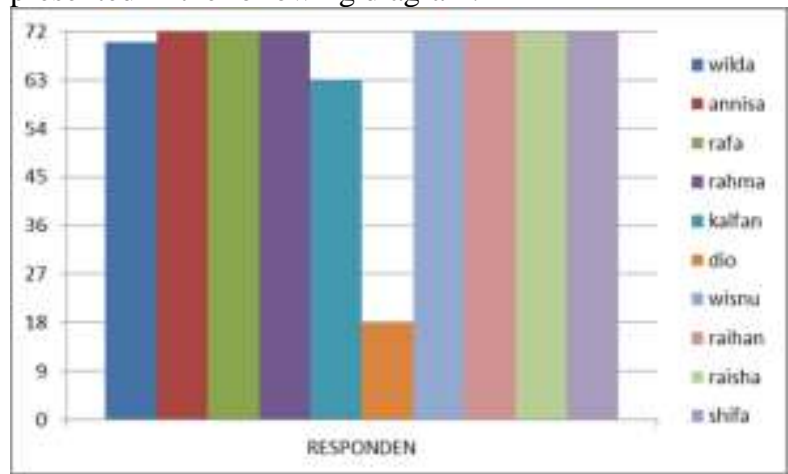

Figure 7 Data on the initial product trial results Effectiveness of mobile learning application

Based on the above data, in a small group trial of 10 (ten) children the mean score was 65.5, Median 72 and deviation default 16.9. Thus, it can be said that the application of Mobile Learning in early childhood at TK Kemala Bhayangkari 1 Serang was carried out effectively.

The second field trial was carried out more broadly in five class groups with a total of 30 children. This stage is focused on developing and improving product material. The following are the results of field trials conducted by Researchers at Bhayangkari 01 Serang Kindergarten on a more broader scope.

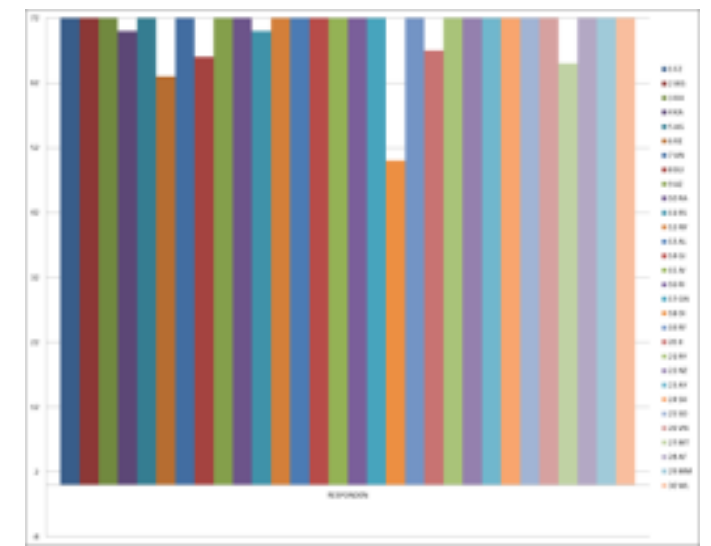

Figure 8 Data field test results effectiveness of applications mobile learning

Based on the results of a broader group trial as part of product improvement made for 30 (thirty) children obtained Mean score of 70.2, Median 72 and standard deviation of 0.33. In other words, the development of mobile learning for early childhood on media subjects and learning resources at the Sultan Ageng Tirtayasa University resulted in a fairly good product.

\section{CONCLUSION}

1) Development of "mobile learning golden age" as a learning medium for early childhood has been developed on android-based mobile phones, it would be better if extensive testing and socialization of PAUD institutions can be conducted throughout Indonesia, especially in Banten Province as an alternative learning media.

2) The presentation of material that is more diverse and coherent in accordance with the level of difficulty of the game needs to be done in the development of mobile learning "golden age" further.

3) Development of "mobile game golden age"with 3D (three-dimensional) shape that contains moving animation. 4) The "golden age" Mobile Game needs to be tested widely in order to get product improvements so that the component level of technological readiness reaches scale 4 .

\section{REFERENCES}

Gall, M. D., Borg, W. R., \& Gall, J. P. (1996). Educational research: An introduction. London: Longman Publishing.

Ibharim, L. F. M., Borhan, N., \& Yatim, M. H. (2013, July). A field study of understanding child's knowledge, skills and interaction towards capacitive touch technology (iPad). In 2013 8th International 
Conference on Information Technology in Asia (CITA) (pp. 1-5). IEEE.

Henderson, S., \& Yeow, J. (2012, January). iPad in education: A case study of iPad adoption and use in a primary school. In 2012 45th Hawaii International Conference on System Sciences (pp. 78-87). IEEE.

Melhuish, K., \& Falloon, G. (2010). M-learning with the iPad. Computers in New Zealand Schools:

Learning, Leading, Technology, 22(3), 1-16. 